\title{
ASSESSMENT OF THE IMPACT OF THE EU STRUCTURAL FUNDS ON BUSINESS IN LATVIA
}

\author{
Iluta Arbidane \\ Madara Tarasova \\ Rezekne Academy of Technologies, Latvia
}

\begin{abstract}
The aim of the paper is to examine the administration of EU structural funds and their influence on business development. The main problem analysed in the paper is administration of the EU structural funds and their implementation in Latvia, the impact of the activities funded by the EU funds onto business development. In the research, information about the essence and policy of the EU structural funds is analysed, including information about the aspects of formation and influence of the EU structural funds, the basic business principles and factors influencing its development, as well as funding by the EU Structural Funds as an instrument for facilitation of business development. In the research, administration of the EU structural funds, the legal framework, and an evaluation of the funds' administration in Latvia, the activities of the EU structural funds for business development in the programming period 2007-2013, influence of the priority "Business development" upon business development in Latgale region, as well as future prospects are discussed. The aim of the paper is to examine the administration of EU structural funds and their influence upon business development. The subject of the research is the impact of EU funds onto business development. In the paper, the following research methods are used: the descriptive or monographic method, aggregation of information, analysis of documentation, statistical analysis, graphical, and the expert method. According to the obtained results, the authors conclude that the activities funded by the EU Structural Funds provide support for enterprises for innovative business development, and increase competitiveness of enterprises, as well as overall business activity.
\end{abstract}

Keywords: business incubators, business development, EU funding, EU structural funds, SMEs

\section{Introduction}

The aim of the paper is to examine the administration of EU structural funds and their influence upon business development. The subject of the research is the impact of EU funds onto business development. In the paper, the following research methods are used: the descriptive or monographic method, aggregation of information, analysis of documentation, statistical analysis, graphical, and the expert method. The following tasks are set to achieve the 
Arbidane \& Tarasova, 2018. Assessment of the Impact of the EU Structural Funds on Business in Latvia

objective:

1. To explore the programmes of the EU Structural Funds that focus on business development and their impact in Latgale region.

2. To carry out a survey of experts and to analyse the survey data on the measures funded by the EU Structural Funds and efficiency of activities during the EU planning period 2007 - 2013.

3. To define the strengths and weaknesses of the EU Structural Funds' Responsible Authorities in absorption of EU structural funds in the planning period of $2007-2013$.

4. To define the opportunities and threats of the EU Structural Funds' Responsible Authorities for effective absorption of EU structural funding in the planning period of $2014-2020$.

5. To draw conclusions and make proposals on introduction of business support tools in Latvia in the planning period of 2014 - 2020 and to recommend the most necessary activities for ensuring business development in Latgale region.

The hypothesis: the EU Structural Funds' activity "Business incubators" is one of the three activities that have left a significant impact on business development.

Latvia became a member of the EU in 2004, and it created opportunities for sustainable development. In ten years from joining to the EU, Latvia had access to more than 10.4 billion euro from the EU Structural Funds and Investment Funds that could be attracted for development. As the result, important infrastructure, transport, communications, water, energy, environmental, cultural, educational and business support projects were implemented, which contributed to the quality of life, prosperity and economic growth. During these years, serious challenges were seen such as the financial crisis of $2008-2009$, the consequences of which we feel even today, the geopolitical and refugee crisis, world countries' strained relations with Russia and Ukraine. All of these events are topical, because, they have both direct and indirect consequences on business, and businesses have to withstand not only competitiveness in the free market conditions, but also aggravating factors that restrict business operations and development, which, in their turn, have a significant impact on the national economy. Nowadays, it is not enough to have a great product that can be traded for a long time without controlling its life cycle and to expect that it will always be in demand. Today, a consumer of goods and services has become queasy, but it has set the competition between manufacturers. In order to enhance the company's competitive and innovative development, the funding is necessary to achieve the objectives, including not only the investments, internal funding, but also grants, loans, subsidies - any funding an entrepreneur can attract from 
external sources. The main problem analysed in the paper is the administration and implementation of the activities funded by the EU Structural Funds, and the impact on business. The novelty of research is the assessed impact of the activities funded by the EU Structural Funds on business activity in Latgale region.

\section{Background of the research study}

Regional disparities in the EU are characterized by significant differences in living standards and employment opportunities. In order to smooth out these differences, it is necessary to provide the free movement of individuals, services, goods, and capital in the EU economic space, as well as to apply the competition policy to control the company's operations and protect the interests of consumers. For each region and each sector to benefit from the single market, the European Union has set up an efficient structural policy framework that is managed and financed by the EU. The ESF is the main instrument that Europe uses to support formation of working places, help people to find better jobs and ensure equal employment opportunities for all EU citizens. Efficient and effective implementation of the actions supported by the ESF depends on good governance and partnership between all relevant territorial and socio-economic actors, taking into account players at regional and local level. Funding from the Structural Funds is usually not used for individual projects. The resources are allocated to the development programmes, and each of them has its own budget.

Across the EU28, the contribution of SMEs in the non-financial business sector is considerable. SMEs make up $99.8 \%$ of all enterprises, $57.4 \%$ (LV $72 \%$ ) of value added, and $66.8 \%$ (LV $79 \%$ ) of employment. In 2015, just under 23 million SMEs in the non-financial business sector generated $€ 3.9$ trillion of value added and employed 90 million people. In general, an economy benefits from a dynamic and constantly changing SME population, in which new products and services are brought to market by new businesses, and firms which are unable to operate on a sustainable basis cease to operate. According to the EU statistical data, the role of SMEs in the economy of the EU has growing significance. It is has to be admitted that, in Latvia, SMEs make up $99.8 \%$ of all enterprises. In accordance with the report, the most pressing problems faced by SMEs in Latvia are finding customers and access to funding.

The SMEs face particular problems due to their small size and limited resources. It is problematic to create a new business and obtain the required capital, as well as find the correct type of funding for the expansion of the established business. Due to the limited resources, SMEs, more than larger companies, suffer from bureaucracy and administrative burdens. It is often hard for the companies to keep track of information and communication technology 
news and to find qualified staff, as well as to provide them with adequate training and education. In addition, for the business owners, who are retired, it is also difficult to find their successors. Currently, the European SME policy has focused mainly on the following five priority areas:

- $\quad$ enhancing entrepreneurial skills,

- improvement of SMEs access to markets,

- bureaucracy control,

- improvement of SMEs growth potential,

- consultations with the parties interested in SMEs (MVU rokasgrāmata, 2016).

The experts' method was applied to determine the following:

- $\quad$ which measures and activities funded by the EU Structural Funds in the planning period of 2007 - 2013 have had a significant effect on business development in Latvia;

- the strengths and weaknesses of the responsible authorities in absorption of EU structural funding in the planning period of 2007 2013;

- the opportunities and threats of the responsible authorities for effective absorption of EU structural funding in the planning period of 2014 - 2020;

- introduction of activities, which would be necessary for business development in Latgale region.

The introduction of innovations in small and medium-sized enterprises is hindered by the lack of own resources; as well the companies face a number of obstacles and greater uncertainty than large enterprises. The studies by economists Wang and Costello show that the level of SME innovation depends on the company's financial and human resources (Wang \& Costello, 2009); however, Todtling and Kaufman indicate that these problems can be partially solved by the integration of enterprises in the networks, innovation systems and reliance on external partners (Totdling \& Kaufman, 2001).

\section{Results and discussion}

Latvia, as the EU member since 2004, actively uses the financial support of the EU Funds for the country's economic and social policy development. In the planning period of 2007 - 2013, Latvia's national economy had access to 4.53 billion euro, while the total available amount of 4.4 billion euro was available in the planning period of 2014 - 2020 (ES Struktūrfondu..., 2015). The business environment is gradually improving in Latvia, which is proved by the economic growth and increased business activity - increase in the number of 
entrepreneurs, investment in fixed assets, and direct foreign investment. However, the Latvian entrepreneurs will be able to maintain the pace of development and create new well-paid working places only if they become competitive at international level, engage in the innovation process, accrue knowledge, and learn new technologies, as well as capture a high added-value niche in the European and global market. The competition of supply, existing in the market, for satisfaction of demand is the most important prerequisite for innovation and technology development, but the current competition is not effective if the business activity is low and the market is composed of small, static number of businesses. In order to promote these essential market characteristics, including the development of competitiveness, the government policy is required to be implemented in a targeted way. Competition policy in Latvia is focused on the minimization of consumers and market participants' loss of potential market distortion, but it should not be limited only to its identification in the activities of market participants. It is important to pay more attention to the national support measures, including the activities funded by the Structural Funds, in order to avoid the possible distortions of competition at this level as well. With the introduction of the national support measures for entrepreneurs funded by the Structural Funds in 2007-2013, it was determined that the activities must have a clear justification and demonstration that they focus on prevention of the existing market failures and support measures are relevant with the importance of the problems to be solved (Darbības programma..., 2007). In the planning period of 2007-2013, the SF support is primarily provided for society's education, technological excellence, and flexibility of businesses, as well as development of science and research in order to promote the knowledge-based economy development in the country and strengthen other necessary preconditions for sustainable economic growth and people's life in Latvia as a whole. Programming of Structural Funds (SF) and the Cohesion Funds (CF) is implemented at three levels: the EU-level strategy or the Community Strategic Guidelines, the strategy of Member States or the National Strategic Reference Framework (NSRF), and the Operational Programme of the Member States. NSRF, on which is based the distribution of 4.53 billion euro worth SF and CF funding available to Latvia in the planning period of 20072013, has been approved by the Cabinet on 19 June, 2007. It was confirmed also by the EC on September 20, 2007. According to the decision of the EU Council of Ministers on the EU's multiannual financial framework for the planning period of 2007-2013, Latvia has received 4.53 billion euro for implementation of the cohesion policy objectives by the means of the EU funds (ERDF, ESF) and the CF (Ziniojums..., 2015). 
The following 4 priorities have been included in the operational program "Entrepreneurship and Innovations":

1. Priority "Science and Innovations" was focused on strengthening of the country's scientific and research potential, enhancing of the international competitiveness, as well as the knowledge transfer and its commercialization. In the measure "Innovations", support was provided to 187 projects and the development of a knowledge based economy, promoting the technology transfer in national economy, establishment of Riga Science and Technology Park, and manufacturing of new products, in accordance with the following activities - Commercialization of science and technology transfer, Development of new products and technologies, Science and Technology Park, High-value investments (Darbības programma..., 2007).

2. Priority “Access to Finances" was focused on promoting access to finance for business development. The objective can be achieved by formation of a comprehensive system of financial instruments, including guarantees, loans, venture capital, and other financial instruments. The only one measure "Accessibility of Financial Resources" has been implemented within the framework of the priority in order to improve the approach of newly created, small, medium, and large businesses to the loan capital by providing guarantees, high-risk financial instruments, as well as to develop the financial market (Darbības programma..., 2007).

3. Priority "Promotion of Entrepreneurship" was focused on stimulation of economic activity and growth of competitiveness by forming new and strengthening existing businesses. The formation of new businesses, as well as contribution to the competitiveness of enterprises, both nationally and internationally, were promoted in order to achieve these goals. Two measures have been implemented within the framework of the priority (Darbības programma..., 2007).

4. The support to the provision of the program's management functions was provided within the framework of the priority "Technical Assistance". In order to improve the management of the ERDF, ensure its simplification, efficiency, and reliability of the management system at the same time, it was necessary to provide the attraction of the technical assistance to the insurance of the program's management functions, as well as to support functions. The measure "Assistance for the Management of the Operational Programme "Entrepreneurship and Innovations" " has been implemented within the framework of the priority (Darbības programma..., 2007). 
In order to assess the achieved results, efficiency of implemented activities, and process of the funds' administration and implementation, the Experts' survey was carried out. The objective of the survey was to determine, which measures and activities financed by the EU Structural Funds in the planning period of 2007 - 2013 have left a significant impact on business development in Latvia and which should be continued to implement in the planning period of 2014 - 2020. The activities, included in the experts' questionnaire, were asked to be ranked in ascending order of importance from 1 to 12 (1- major impact). Based on the obtained and summarised data on the Question 1, in which experts had to rank the EU funded activities by their importance to business development (Table 2.3), the authors conclude that the experts consider the following activities having the greatest impact on business development in Latvia: conquering the external markets; business incubators; investment support for micro, small and medium-sized enterprises in especially supported areas.

Table 1 Experts' rank of activities, listed by importance and based on the Experts' Survey (Source: compiled by the authors)

\begin{tabular}{|c|l|c|}
\hline $\begin{array}{c}\text { Activity } \\
\text { No.* }\end{array}$ & \multicolumn{1}{|c|}{ Activity** } & Rank*** \\
\hline 1 & Conquering external markets & $2-3$ \\
\hline 2 & $\begin{array}{l}\text { Measures to increase motivation, innovation and starting a } \\
\text { business }\end{array}$ & 5 \\
\hline 3 & Business incubators & $2-3$ \\
\hline 4 & $\begin{array}{l}\text { Investment support for micro, small and medium-sized enterprises } \\
\text { in especially supported areas }\end{array}$ & 1 \\
\hline 5 & Cluster programme & 9 \\
\hline 6 & Commercialization of science and technology transfer & $7-8$ \\
\hline 7 & Development of new products and technologies & 4 \\
\hline 8 & Science and technology park & $7-8$ \\
\hline 9 & Investments of high added value & 10 \\
\hline 10 & Support for science and research & 11 \\
\hline 11 & $\begin{array}{l}\text { Support for international cooperation projects in science and } \\
\text { technology }\end{array}$ & 6 \\
\hline 12 & Development of science and research infrastructure & \multicolumn{1}{|c|}{} \\
\hline
\end{tabular}

* Activity No. - activity's sequence number in the Question 1 of the Experts' questionnaire.

** Activity - Title of the activity for business development funded by the EU SF.

*** Rank - Activities' significance rank, formed by collecting each expert's assessment for each activity, listing them in order of importance. 
Although business activity takes place mainly in national and regional development centres, inhabitants have access to the state and municipal services in electronic form at any place in Latvia, as well as in single customer service centres. Even though the publicity measures of the activities implemented are reflected in the information space, the authors believe that a relatively narrow circle of society is aware of the results achieved and the opportunities provided by the EU Structural Funds, so the achieved performance indicators could be higher.

According to data obtained from the experts' survey, it can be concluded that the greatest contribution of the activities funded by the EU funds are of those, which have been implemented directly for business activity stimulation and provision of entrepreneurship in the regions, such as conquering of external markets, business incubators, and investment support for micro, small and medium-sized enterprises in especially supported territories. According to the experts' replies, the authors conclude that the EU Structural Funds' support for the development of innovations is significant, which, as mentioned above, is a business' driving force nowadays. According to experts, the activity of business incubators can be considered as a major and significant contribution to business provision in Latgale region. In order to promote formation and development of micro, small, and medium-sized enterprises, Latvian Investment and Development Agency (LIAA) implemented a co-funded project "Development of Business Incubators in Latvia" together with the ERDF from 2009 to the end of 2014. In 2014, a new procurement of transitional period for business incubator operators was announced, which prolonged the incubation service availability period until 31 October, 2015. The total available public funding of the activity was 28.4 million euro, which was formed by 24.43 million euro (85\%) of the ERDF and 4.31 million euro (15\%) of the national budget of Latvia. The activity "Business Incubators" in Latgale region was implemented by the association "Latgale Machinery and Technology Centre" (LMTC) and the Business Incubator "Ideju viesnīca" that was a business incubator network in Latgale, established in 2009 in order to promote the establishment and development of new, viable and competitive enterprises in Latgale region. The Business Incubator "Ideju viesnīca" was the activity realized by LMTC in the region of Latgale (in the Latgale Planning Region 1 and 2) within the framework of the project carried out by the LIAA.

During the period from 2009 to 2014, Business Incubator "Ideju viesnīca", managed by its operator "Latgale Machinery and Technology Centre", reached the number of 193 SMEs, which meant an increase rate of 13.79 since 2009, that is, up to 88 businesses in Rezekne and 105 in Daugavpils (see Figure 1) by 
2014. As a result, the number of working places has increased, which amounted to more than 323 in BI companies by the end of 2014.
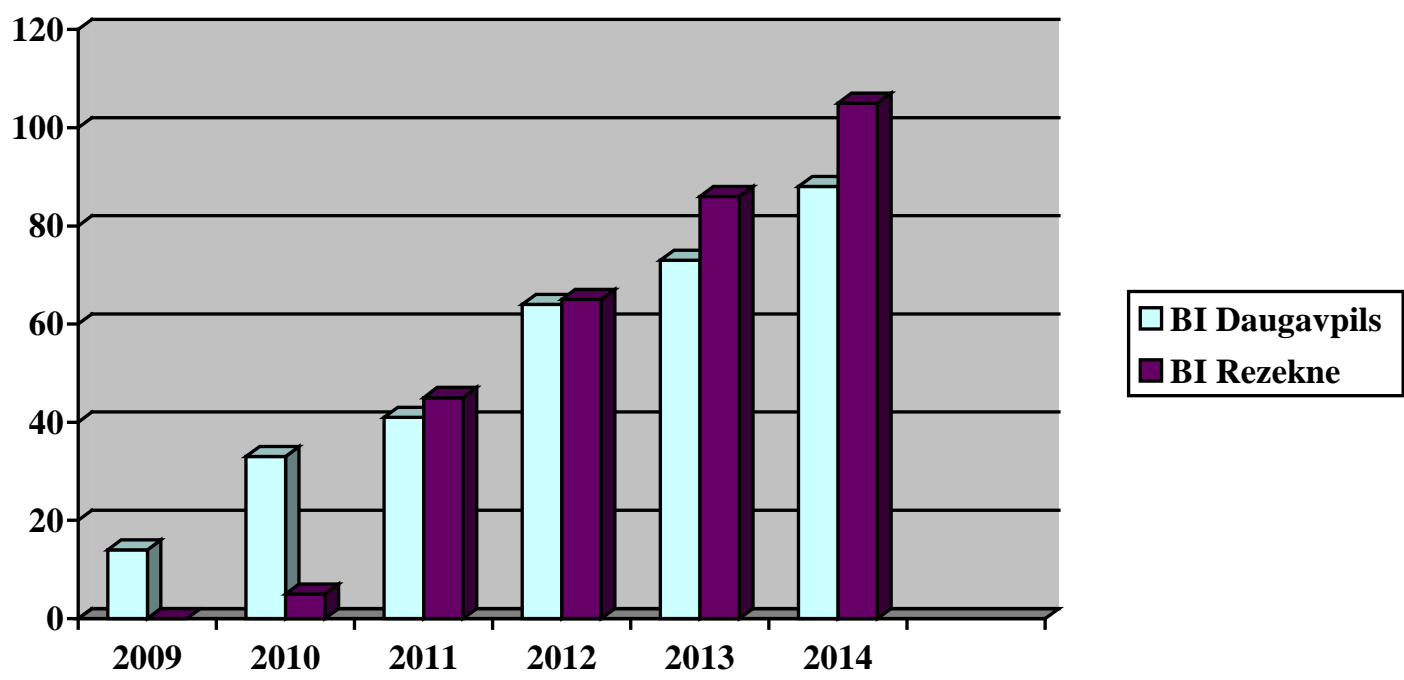

Figure 1. The number of small and medium-sized enterprises in BI "Idea hotel" in Rezekne and Daugavpils from 2009 to 2014 (Source: BI “Idea hotel”)

It can be concluded that the number of businesses was 1.17 times higher in the BI Daugavpils area than in the BI Rezekne area. An important factor is that there is a larger number of population and higher business activity in Daugavpils BI area. New companies widely used the range of services provided by BI, subsidies, aid intensity for specialized or minimum services, absorption of de minimis aid amount, support for business start-up, additional funding opportunities, consultation on financial and legal issues or technological processes, participation in international exhibitions and fairs. Essentially, SMEs not only received support for the implementation of their ideas, but also "refunded" that amount by the taxes paid.

The total amount of taxes paid from 2009 to 2014, that is, within the timeframe of the activity, was 393567.66 EUR, or just by $13.39 \%$ smaller than the amount of de minimis received by SMEs. However, the amount of tax payments was 1.79 times higher than the amount of the received de minimis in 2014, and it can be concluded that, starting with that moment, the finances committed started to return to the State Treasury in form of tax payments. The companies involved in the activity "Business Incubators" were able to carry out production in a more productive way and to focus on the products' availability on the market with the support and subsidies, using, for example, marketing services. The start of exports is the most popular, fast and easy way for a small company to start international operations; compared to other market acquisition 
models, it requires less administrative resources, provides greater leeway and is associated with a lower risk.

Thecompanies of BI "Ideju viesnīca" reached a total turnover of 22783 729 EUR in the period from 2009 to 2014, $36 \%$ of which are exports to the other countries. The companies of Rezekne’s BI have exported by 989923 EUR more than Daugavpils’ BI.

Taking into account experience of the EU funding period of 2007 - 2013, as well as opinions provided by the municipalities and entrepreneurs, the business incubators' implementation model has been changed in the planning period 2014 - 2020. The program's implementation in the previous period demonstrated that the incubation services for new entrepreneurs are needed in whole Latvia, but they were available only in certain regions and of very different quality. In the future, the incubation services to the regions will be provided by LIAA, developing structural units outside Riga.

TheEU funds provide support for new SMEs directly at early stages of development and when they are shifting to other markets, introduce new products and innovation, in the case of precarious economic situation in the country and the world; the BI services help to find solutions to the problems or provide ideas for new directions of development.

Based on the Experts' replies on what should be done to develop business in the region of Latgale effectively, the authors conclude that the most important activities are the following:

- implementation of infrastructure development projects in the cities of national significance and regional centres, including infrastructure of streets and roads, engineering communications;

- provision of the financial resources' availability for regional businesses (co-funding and pre-funding of projects);

- provision of support for new micro and small businesses for manufacturing and development of new services (investment in modernization of production facilities, investment in business infrastructure, investment in production equipment);

- introduction and promotion of private accelerators;

- attraction of new investors in order to ensure the development of technology, IT and manufacturing;

- $\quad$ successful implementation of the Latgale Special Economic Zone to encourage business development and investment attraction;

- $\quad$ support and promotion of the creation of new jobs as well as the establishment of business with the use of grants;

- provision of quotas for regions when planning the resources, thereby ensuring smooth resource allocation throughout the country. 


\section{Assessment of EU structural fund administration in Latvia}

In order the EU Structural Funds' statistics on the funding spent would show not only the amount of money invested in co-funding of various projects, but as well the indicators achieved by, for example, an increase in production and exports, the strictly designed administration procedure and set out obligations and responsibilities of the EU fund management institutions are required. The Ministry of Finances as the managing authority of the EU fund administration continuously has carried out the EU funds management system upgrades in the planning period of 2007 - 2013, and the State Control office's audit in addition is a positive assessment of the external auditor that allows improving the system even more significantly. Due to the fact that the duties of the Responsible Authority for the EU funds was carried out by 8 ministries and the State Chancellery in the planning period of 2007-2013, each of these institutions was responsible for ensuring that the project activities and implementation of the activities facilitate the development of the sector represented by the ministry and it would be implemented, based on the sector development policy. Based on the Expert's Survey and collecting the responses to the questions on the strengths and weaknesses of the Responsible Authorities in the EU Structural Funds planning period of 2007-2013, the authors have carried out SWOT analyses.

Strengths:

- Clear system and methodology for fund resources' administration;

- Informative campaign, workshops, etc. on calls for project proposals;

- $\quad$ Experience in the administration of the EU funds;

- Teams of specialists who coordinate the implementation of activities;

- $\quad$ Knowledge of the sector;

- Electronic management information system;

- $\quad$ Ensured access to the Structural Funds in all the territory of Latvia.

- Weaknesses:

- $\quad$ Exaggerated bureaucratic requirements;

- Incompetence of officials;

- Delayed or late project implementation deadlines;

- $\quad$ Requirement changes during the project implementation;

- $\quad$ Fragmented support programme that makes the administration process difficult;

- Turnover of staff;

- Lobbying;

- $\quad$ Little assistance to the support beneficiaries; 
Arbidane \& Tarasova, 2018. Assessment of the Impact of the EU Structural Funds on Business in Latvia

- Planning of business promotion activities and measures, without taking into account regional specificities;

- Inflexibility and inability to adapt to changing business environment conditions;

- $\quad$ Too slow cash returns to projects' implementers.

According to the Experts' survey, the authors conclude that the experts welcome the results the Responsible Authorities' work in their responses, because, in essence, they have had a positive impact on each industry, representing the Responsible Authorities. The authors found that the greatest advantage is the competence of the Responsible Authorities and the availability of information about the industry, represented by the Ministry, and experience in the implementation of the EU funds. Although the electronic systems, which facilitated the submission of projects, reports, etc. documents, were introduced at the end of the planning period of 2007 - 2013, however, bureaucratic requirements were mentioned by the experts as the most negative aspect. The planned income often does not outweigh the investments, provided in order to obtain the EU funding. As pointed out by the experts, the excessive use of legislative norms often takes place. The authors concluded that the factor, which hinders the development of regions and does not give the expected results, is the planning of business promotion activities and measures, without taking into account regional specificities and needs. Conclusion is the following: a full research, where the region's residents, operating companies, representatives and support beneficiaries of municipalities, educational institutions, and intermediary bodies have a key role, on each region is not carried out in the development process.

The authors conclude that it is a voluminous work in the preparation, implementation, and monitoring and evaluation process. Starting the planning period of 2014 - 2020, the aspects, forming a negative impression on the EU Structural Funds' administration, must be taken into account first and foremost. On the basis of the Experts' Survey and the replies to the question on the opportunities and threats of the Responsible Authorities of the EU Structural Funds for an effective absorption of EU structural funding in the planning period of 2014 - 2020, the authors concluded that the effectiveness of structural funding absorption can be achieved by optimization of the bureaucratic requirements and project implementation procedures for the applicants, reducing the deadlines of the project evaluation, cash return, etc.

Opportunities:

- Reduced bureaucratic requirements, imposed by the national government to the businessmen' projects;

- $\quad$ Reduced deadlines of the project evaluation and decision-making; 
- Closer cooperation with the industry associations and private sector;

- Quick response to changes in financial outturn distribution of the specific support objectives;

- Development of the interim results' achievement system;

- Consideration of the procurement process as force majeure that significantly changes the duration and sums of a well-planned project;

- Usage of the lessons learned from the previous period, planning of activities that are important for Latvian and regional business environment;

- Usage of the business support institutions established in the previous Threats: programming period in order to continue the current job successfully.

- Lack of financial resources for pre-financing of the businessmen projects and co-funding for their businesses, reduced aid intensity for businessmen projects;

- $\quad$ Reduced number of applicants for the EU Structural Funds' projects due to the limited financial resources and restricted programmes;

- $\quad$ Lost time in connection with adoption of the Cabinet regulations;

- Amendments to the Public Procurement Law. Inability to perceive the enforcement security of the Procurement Law in municipalities as force majeure and thereby contributing to the realization of lowquality projects;

- Too diligent execution of the EU regulation norms, despite the fact that Latvia may apply only those provisions, which have been incorporated into the Latvian legislation;

- Implementation of too risky projects, thus not reaching the expected results. Reputation of the responsible authorities may suffer due to the incomplete assessment of risks;

- $\quad$ Falling behind the absorption of means and losing funding after the interim evaluation.

Introduction of the EC initiative's E-cohesion is set a priority in the EU funds project administration, providing the opportunity to organize the movement of all of the project related documentation electronically. Document storage, reporting and other processes and the external environment of the EU funds' Management Information System, available to the beneficiaries, are carried out electronically. The implementation of additional functionality, including the possibility to submit the project application electronically, is envisaged in the planning period of 2014 - 2020. The number of the institutions, involved in the EU funds management, is reduced in the planning period of 2014 - 2020, which will be reflected in the EU funds communication process. The 
investment process of the EU funds' investment becomes simplified, decreasing the bureaucratic barriers. There is a possibility that this will ensure greater transparency, as well as effective and planned communication will lead to a higher level of understanding of different target groups on the effectiveness and benefits, implemented by the EU funds and provided to each resident of Latvia. According to the Experts' replies, the amendments in legislation, the Public Procurement Law, the rules for implementation of activities and requirements cause threats. Negative effects can be caused by falling behind the adoption of Regulations of the Cabinet of Ministers on the coordination of the European Union funds' support programmes. In the long term, it can lead to unused funding that could be invested in development by the aid applicants. Despite the positive examples and the work done by the Responsible Authorities in the previous planning period, the introduction of high-risk projects, which have been unable to achieve the necessary results, have formed negative effects. Due to inadequate assessment of risks and monitoring, reputation of the Responsible Authorities has decreased.

Based on the replies, submitted by the Experts, it can be concluded that the most important task for the effective absorption of the structural funding is to set goals, objectives and directions, where the development of the national economy will be guided. The invested funds can produce results if they are used wisely and for solving the most important issues.

\section{Conclusions and suggestions}

Both the Experts and the author consider that a major and significant contribution to the business provision in Latgale region is the activity of the business incubators - a structural unit, established for the encouragement of the national or regional economy and social development, and whose task is to evaluate and support start-ups and growth of new business.

When developing the EU funds' planning documents and regulations of the Cabinet of Ministers, providing the implementation of activities or measures, the institutions involved in EU fund management (the Ministry of Finances as the Managing Authority) and the responsible authorities (sector ministries) should set guidelines that will reduce the bureaucratic requirements, the number of procedures and time in the project implementation process, deadlines of project evaluation, submission of documents in the "paper" version and money return, and will increase the number of beneficiaries who will receive EU funding for operational growth, thus increasing competitiveness in the local and export markets, sales and profits.

When developing normative acts for the administration and implementation of EU structural funding, the Ministry of Finance and sector ministries should 
analyse the economic situation in the country and the world and predict the potential risks in the activities/programme implementation process and determine the guidelines and solutions precisely to ensure that no requirement changes will appear during the project implementation that would hinder the implementation of the projects, increase expenses of the aid beneficiary, and cause the delay or failure of the project implementation.

When creating the business incubators in the centres of national importance and their structural units, the Ministry of Economics and LIAA should ensure regular publicity events, online or off-site seminars, guest lectures in the city and regional centres, schools, higher education institutions, which will be information provided on the BI services and support opportunities in order to encourage and motivate young entrepreneurs and authors of ideas to take up economic activities. As a result, the number of employees, the amount of taxes paid, the territory's competitiveness and investment in the region will increase.

\section{References}

Annual Report on European SMEs 2015. (2016). Retrieved from April 20, 2016, https://ec.europa.eu/growth/smes/business-friendly-environment/performance-review2016 ISBN 978-92-79-62839

Darbības programma „Uzñēmējdarbība un inovācijas”. (2007). Retrieved April 20, 2016, from http://www.esfondi.lv/upload/04-kohezijas_politikas_nakotne/dp_aktivitates/2dp/ 2DP_11022014_LV_ar_konsolidetiem_grozijumiem.pdf

Eiropas Savienības Struktūrfondu un Kohēzijas fonda 2014. -2020. gada plānošanas perioda komunikācijas stratēgija 2015.-2023. gadam. (2015). Retrieved April 23, 2016, from http://www.esfondi.lv/upload/14-20_gads/ES_fondu_Komunikacijas_strategija_20152023_LV.pdf.

Kalniņa, I., \& Strazda, A. (1999). Eiropas Savienības reǵionālā politika un strukturālie fondi. 3. redakcija. Rīga, McĀbols. 31 lpp.

MVU rokasgrāmata. (2016). Retrieved April 25, 2016, from http://ec.europa.eu/social/ BlobServlet?docId $=4202$ \&langId=lv.

Todtling, F., \& Kaufman, A. (2001). The Role of the Region for Innovation Activities of SMEs. European Urban and Regional Studies.

Wang, Y., \& Costello, P. (2009). An Investigation into Innovations in SMEs: Evidence from the West Midlands. UK Journal of Entrepreneurship, Vol. 18, Iss: 1, 65-93.

Ziņojums par tautsaimniecības attīstību. (2015). LR Ekonomikas ministrija. Retrieved April 28, 2016, from

https://www.em.gov.lv/files/tautsaimniecibas_attistiba/zin/2015_dec_lv.pdf. Biedrības LATC struktūrvienības Biznesa inkubatora „Ideju viesnīca” darbības rādītāji. 